\title{
Structural Interpretation of Lineaments by Satellite Image Processing (Landsat TM) in the Region of Zahret Medien (Northern Tunisia)
}

\author{
Sonia Gannouni*, Hakim Gabtni \\ Laboratoire de Géoressources, Centre de Recherches et des Technologies des Eaux, Technopôle Borj-Cedria, \\ Soliman, Tunisia \\ Email: "gannouni sonia@yahoo.fr
}

Received 13 March 2015; accepted 5 April 2015; published 10 April 2015

Copyright (C) 2015 by authors and Scientific Research Publishing Inc.

This work is licensed under the Creative Commons Attribution International License (CC BY).

http://creativecommons.org/licenses/by/4.0/

(c) (i) Open Access

\begin{abstract}
There are several techniques that were developed for determining the linear features. Lineament extraction from satellite data has been the most widely used applications in geology. In the present study, lineament has been extracted from the digital satellite scene (Landsat 5, TM data), in the region of Zahret Median situated in the north west of Tunisia. The image was enhanced and used for automatic extraction. Several directions of features were mapped. The directions of major invoices are NE-SW and NW-SE oriented. The validation of the obtained results is carried out by comparison with the results geophysics as well as to the studies previous of mapping developed in the sector of study.
\end{abstract}

\section{Keywords}

Linear Features, Satellite Image, Filter, Automatic Extraction, Direction

\section{Introduction}

The geographical situation between the Mediterranean Sea and Sahara makes Tunisia a dry country on the major part of its territory. This aridity, conjugated to the variability of the Mediterranean climate, makes the water a rare resource and unevenly distributed in time and space. Tunisia is classified by the international bodies as being among the least endowed countries in subterranean water resources in the pond of the Mediterranean (World Bank, FAO, OMS, UNESCO). The study of features is fundamental to the research in subterranean waters. In-

\footnotetext{
${ }^{*}$ Corresponding author.
}

How to cite this paper: Gannouni, S. and Gabtni, H. (2015) Structural Interpretation of Lineaments by Satellite Image Processing (Landsat TM) in the Region of Zahret Medien (Northern Tunisia). Journal of Geographic Information System, 7, 119-127. http://dx.doi.org/10.4236/igis.2015.72011 
deed, the main part of water resources is in fractured aquifers [1]-[5].

The remote sensing thanks to its synoptic vision has been increasingly used for the mapping of the surface and for evaluation of natural resources. Landsat thematic Mapper data in digital format were preferred data due to the availability of seven bands ranging from visible to mid-infrared with $30 \mathrm{~m}$ spatial resolution, and one thermal band with $60 \mathrm{~m}$ spatial resolution; this permitted a large spectrum of band combinations, useful in visual and automatic interpretation of different features [1] [3] [6]-[10].

\section{Domain of Study}

The zone of study is situated in the region of Zahret Median in the North West from Tunisia (Figure 1). The morpho-structural plan in Zahret Median is characterized by impressive reliefs with abrupt slopes and narrow valleys. The sector of study contains two structural units interpreted by Rouvier [11] [12]: The "Kasseb unity" and the "Numidian unity".

The Kasseb unity is constituted by three series: yprésien carbonated series, clayey lutétienne and of a detrital series of the lower Oligocene. The "numidian unity" is constituted by a material flyschoide silici-clastique surmounting by tangential contact all native and nonnative (native and allochthonous, autochthonous and nonnative) grounds Kasseb unity being in the South [11] [13]. The studied domain contains a dense river system and made an incision with permanent rivers and in numerous sources of water. The rivers main things are river Kasseb draining the pond overturning of the syncline of Kasseb and passing by of the NW towards it up to the plain of Majerda where it makes a junction with river Majerda and river Maaden, draining the valley of river Maaden and passing by known SW towards was born to the zone of Hédils. Of a lesser importance river el Blaaa, river Bou Naîl, river El Brik and river Snain who join in the syncline of Kasseb [11] [12].

\section{Materiels and Methods}

The datasets used include subsets, published geological, topographic maps of the region Zahret median (at scales 1:200,000 and 1/25,000) and Landsat 5 TM image. The Landsat 5 Thematic Mapper (TM) of 04 July 1985 (Figure 1), was downloaded free from the Global Land Cover Facility homepage

(http://earthexplorer.usgs.gov/). This period corresponds to the dry season which is characterized by absence of

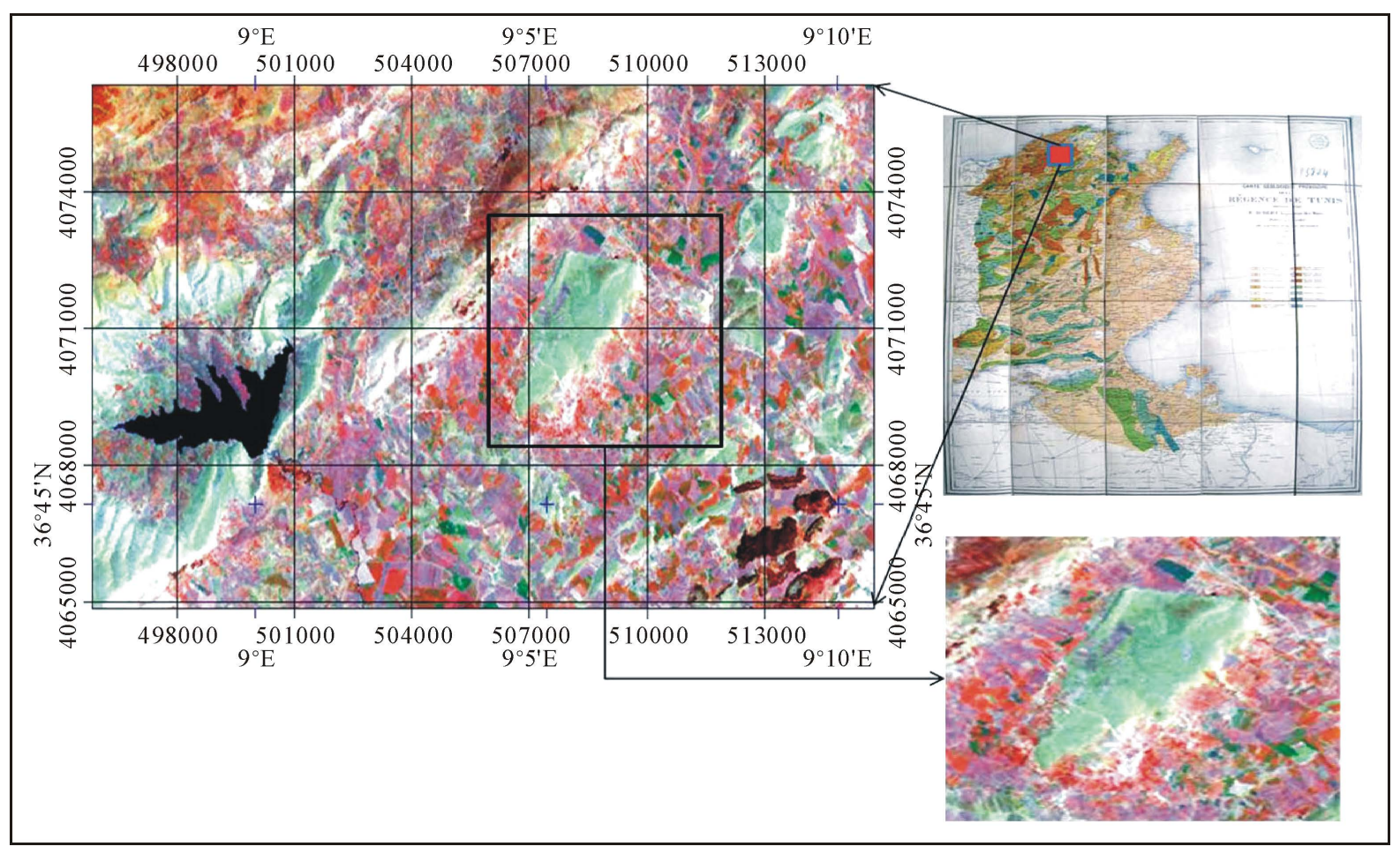

Figure 1. Location of study area. 
clouds, what contributes to the good visibility of the sensors as regards Landsat. According to Youan Ta and al [14] [15], these satellite images were chosen because of their spectral and spatial characteristics allowing a good structural small-scale mapping. The spatial resolution is $30 \mathrm{~m}$ for the reflective bands. These are band $1(0.45$ $0.52 \mu \mathrm{m})$, band $2(0.52-0.60 \mu \mathrm{m})$, band $3(0.63-0.69 \mu \mathrm{m})$, band $4(0.76-0.90 \mu \mathrm{m})$, band $5(1.55-1.75 \mu \mathrm{m})$ and band 7 (2.08 - $2.35 \mu \mathrm{m})$. The spatial resolution of panchromatic (band 8) and thermal infrared (band 6 (10.4 - $12.5 \mu \mathrm{m}$ )) bands are $14.25 \mathrm{~m}$ and $56 \mathrm{~m}$ respectively. The approximate scene size is $170 \times 183 \mathrm{~km}$.

Geological Structural investigation such as lineament mapping is normally undertaken based on geomorphological features, such as aligned ridges and valleys, displacement of ridge lines, scarp faces and river passages, straight drainage channel segments, pronounced breaks in crystalline rock masses and aligned surface depression [16]-[20].

The first step of the methodology is the selection of initial input data for lineament extraction. A Digital image processing for the extraction of linear features involving contrast stretching, Image enhancement, Principal Component Analysis (PCA) were carried out on the satellite data using ENVI 4.7 software. Color composite of bands 1, 2 and 3 of the Landsat 5 Thematic Mapper images bands were made (Figure 2) and (Table 1).

A convolution filtering algorithm involving Directional Gradient-Sobel filters was applied on the enhanced Images in N-S, E-W, NE-SW and NW-SE directions to increase frequency and contrast of the images. Table 2 shows the directional filters in its four principal directions.

The automatic lineament extraction process was carried out with LINE module of PCI Geomatica V9.1 based on automatic detection algorithms [21].

\section{Results and Discussion}

The analysis of the networks of major fractures of this region obtained after the diverse treatments of the image Landsat TM, proves the existence of the dominant orientations of lineaments. The lineaments were extracted from the Figures 3-6 and Figure 7. Table 3 shows the summary statistics of the extracted lineaments.

The lineament map (Figure 3) represents all the fractures carried out of the filtering the South (filter $0^{\circ}$ ), it groups 9 lineaments with a total length of $18 \mathrm{~km}$. The diagram of frequency associated with this map shows an ascendancy of the lineaments of NW-SE trend.

The second map of fracturing obtained by filtering SW shows a homogeneous distribution of lineaments. The statistical analysis of lineaments indicates a preferential direction NW-SE (Figure 4).

\section{Table 1. Summary statistics of Principal Component Analysis (PCA).}

\begin{tabular}{ccc}
\hline Principal component & Value & \% for information \\
\hline 1 & 6994.1323 & 81.87 \\
2 & 1438.5044 & 16.83 \\
3 & 87.5044 & 1.02 \\
4 & 14.5575 & 0.17 \\
5 & 6.6845 & 0.07 \\
6 & 1.11 & 0.01 \\
\hline
\end{tabular}

Table 2. Sobel filters $5 \times 5$ in four main directions applied in this study.

\begin{tabular}{|c|c|c|c|c|c|c|c|c|c|c|c|c|c|c|c|c|c|c|c|}
\hline \multicolumn{5}{|c|}{ North west } & \multicolumn{5}{|c|}{ West } & \multicolumn{5}{|c|}{ South west } & \multicolumn{5}{|c|}{ South } \\
\hline 3 & 2 & 2 & 1 & 0 & 1 & 1 & 0 & -1 & -1 & 0 & -1 & -2 & -2 & -3 & -1 & -2 & -3 & -2 & -1 \\
\hline 2 & 4 & 3 & 0 & -1 & 2 & 3 & 0 & -3 & -2 & 1 & 0 & -3 & -4 & -2 & -1 & -3 & -4 & -3 & -2 \\
\hline 2 & 3 & 0 & -3 & -2 & 3 & 4 & 0 & -4 & -3 & 2 & 3 & 0 & -3 & -2 & 0 & 0 & 0 & 0 & 0 \\
\hline 1 & 0 & -3 & -4 & -2 & 2 & 3 & 0 & -3 & -2 & 2 & 4 & 3 & 0 & -1 & 1 & 3 & 4 & 3 & 2 \\
\hline 0 & -1 & -2 & -2 & -3 & 1 & 1 & 0 & -1 & -1 & 3 & 2 & 2 & 1 & 0 & 1 & 2 & 3 & 2 & 1 \\
\hline
\end{tabular}



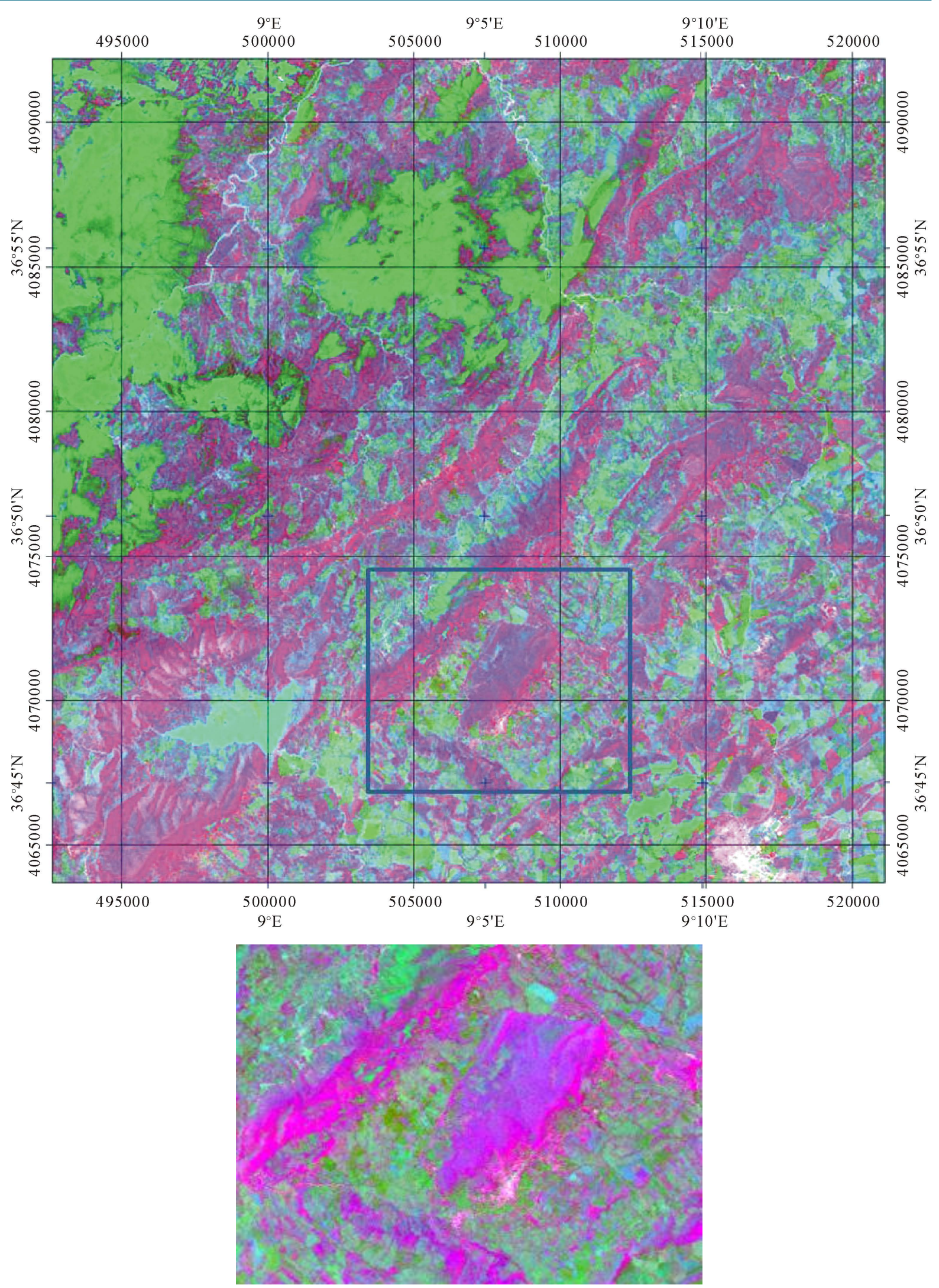

Figure 2. False color composite of PCA 1 (Red), 2 (Green), and 3 (blue). 

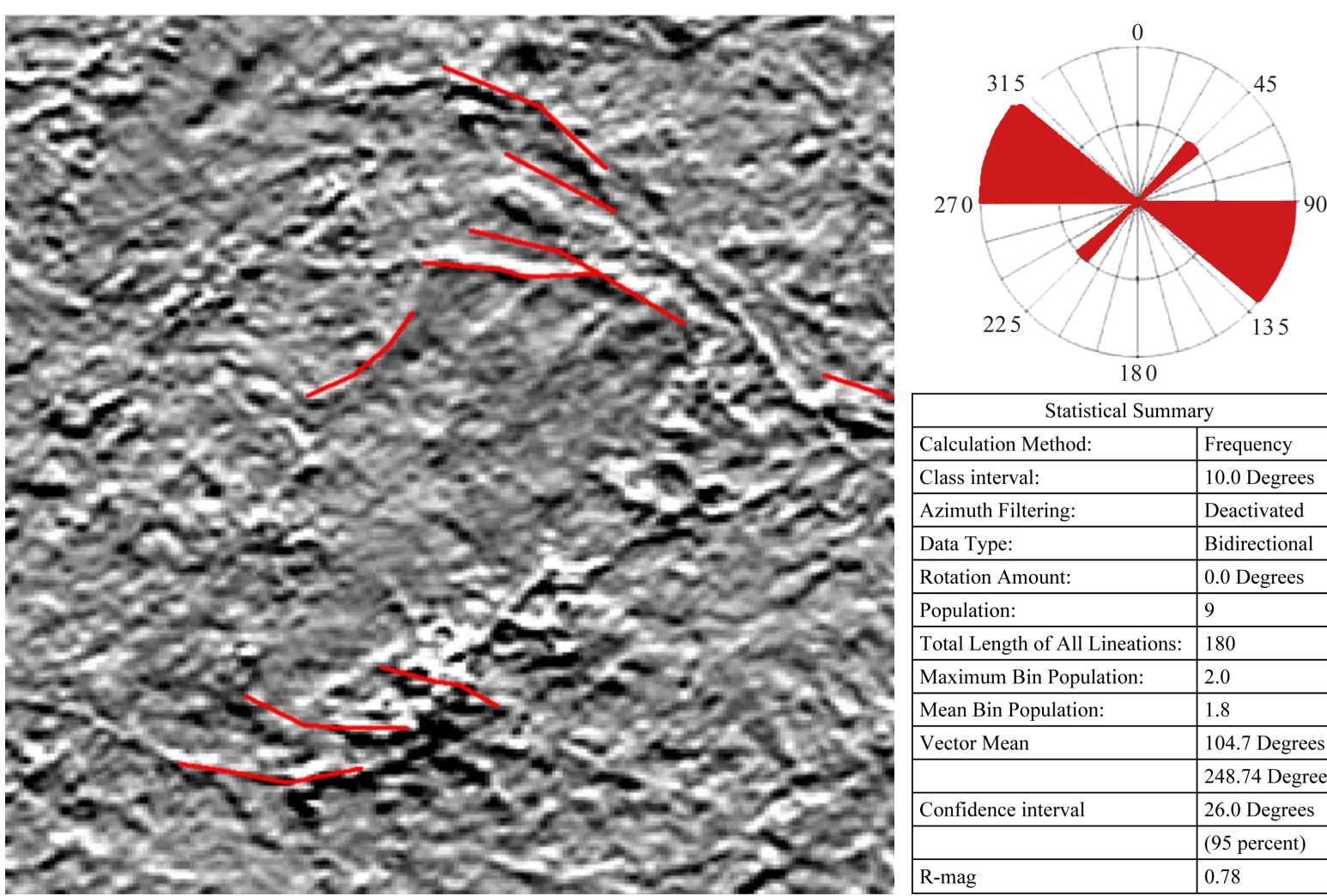

\begin{tabular}{|l|l|}
\hline \multicolumn{2}{|c|}{ Statistical Summary } \\
\hline Calculation Method: & Frequency \\
\hline Class interval: & 10.0 Degrees \\
\hline Azimuth Filtering: & Deactivated \\
\hline Data Type: & Bidirectional \\
\hline Rotation Amount: & 0.0 Degrees \\
\hline Population: & 9 \\
\hline Total Length of All Lineations: & 180 \\
\hline Maximum Bin Population: & 2.0 \\
\hline Mean Bin Population: & 1.8 \\
\hline Vector Mean & 104.7 Degrees \\
\hline & 248.74 Degrees \\
\hline Confidence interval & 26.0 Degrees \\
\hline & (95 percent) \\
\hline R-mag & 0.78 \\
\hline
\end{tabular}

Figure 3. Map lineament and rose diagram of the south direction (filtre $00^{\circ}$ ).
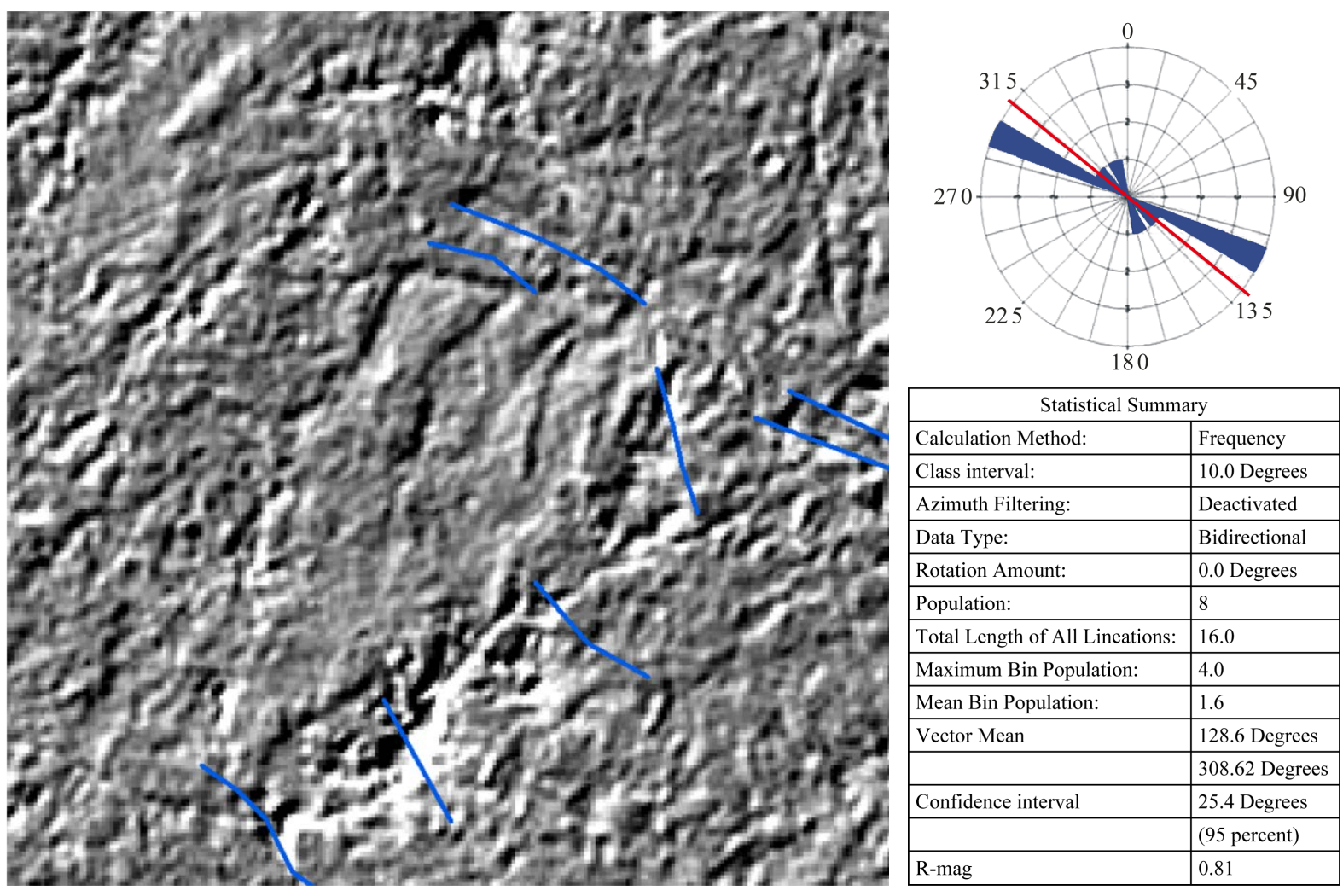

Figure 4. Map lineament and rose diagram of the south west direction (filtre $45^{\circ}$ ). 

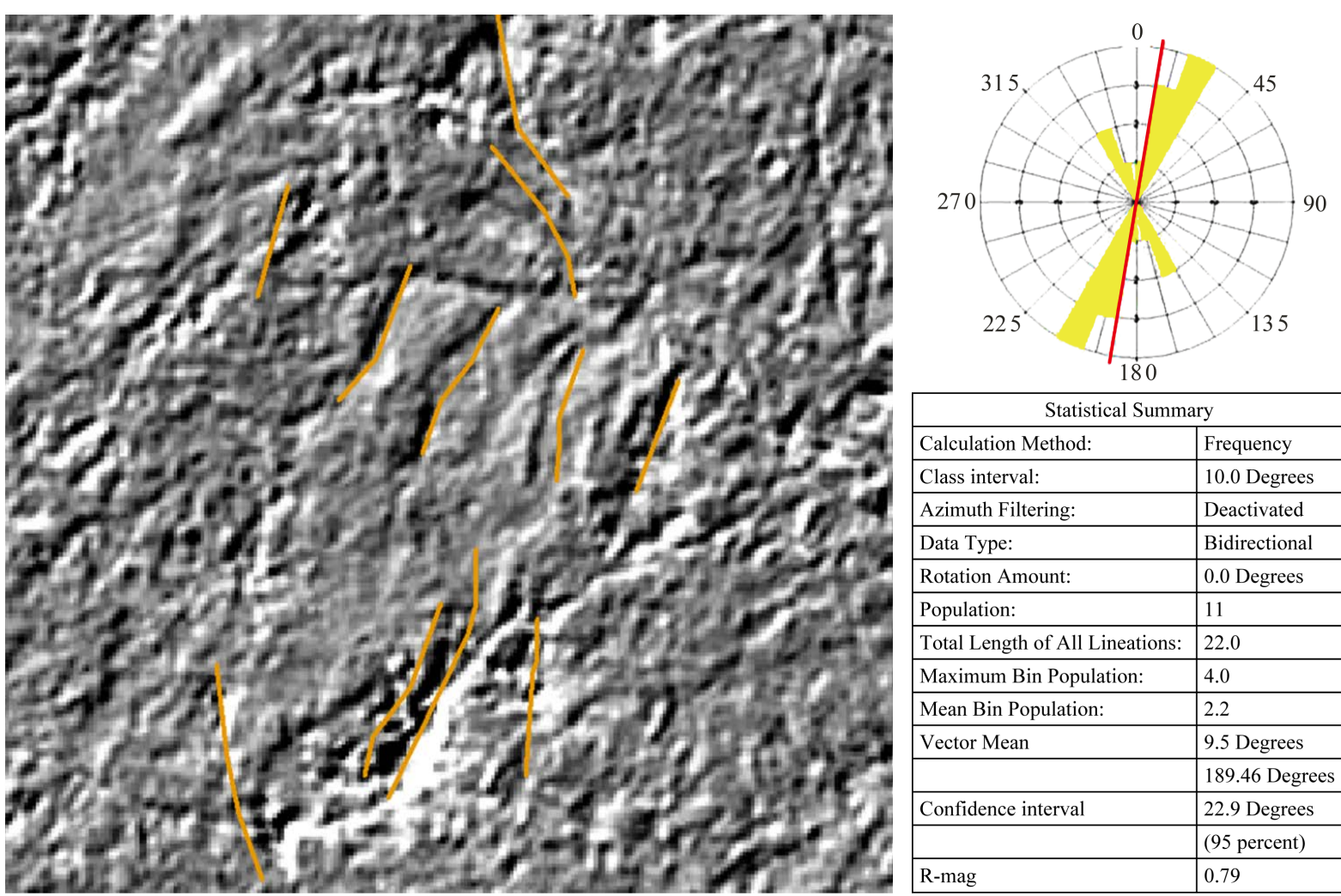

\begin{tabular}{|l|l|}
\hline \multicolumn{2}{|c|}{ Statistical Summary } \\
\hline Calculation Method: & Frequency \\
\hline Class interval: & 10.0 Degrees \\
\hline Azimuth Filtering: & Deactivated \\
\hline Data Type: & Bidirectional \\
\hline Rotation Amount: & 0.0 Degrees \\
\hline Population: & 11 \\
\hline Total Length of All Lineations: & 22.0 \\
\hline Maximum Bin Population: & 4.0 \\
\hline Mean Bin Population: & 2.2 \\
\hline Vector Mean & 9.5 Degrees \\
\hline & 189.46 Degrees \\
\hline Confidence interval & 22.9 Degrees \\
\hline & $(95$ percent $)$ \\
\hline R-mag & 0.79 \\
\hline
\end{tabular}

Figure 5. Map lineament and rose diagram of the west direction (filtre $90^{\circ}$ ).
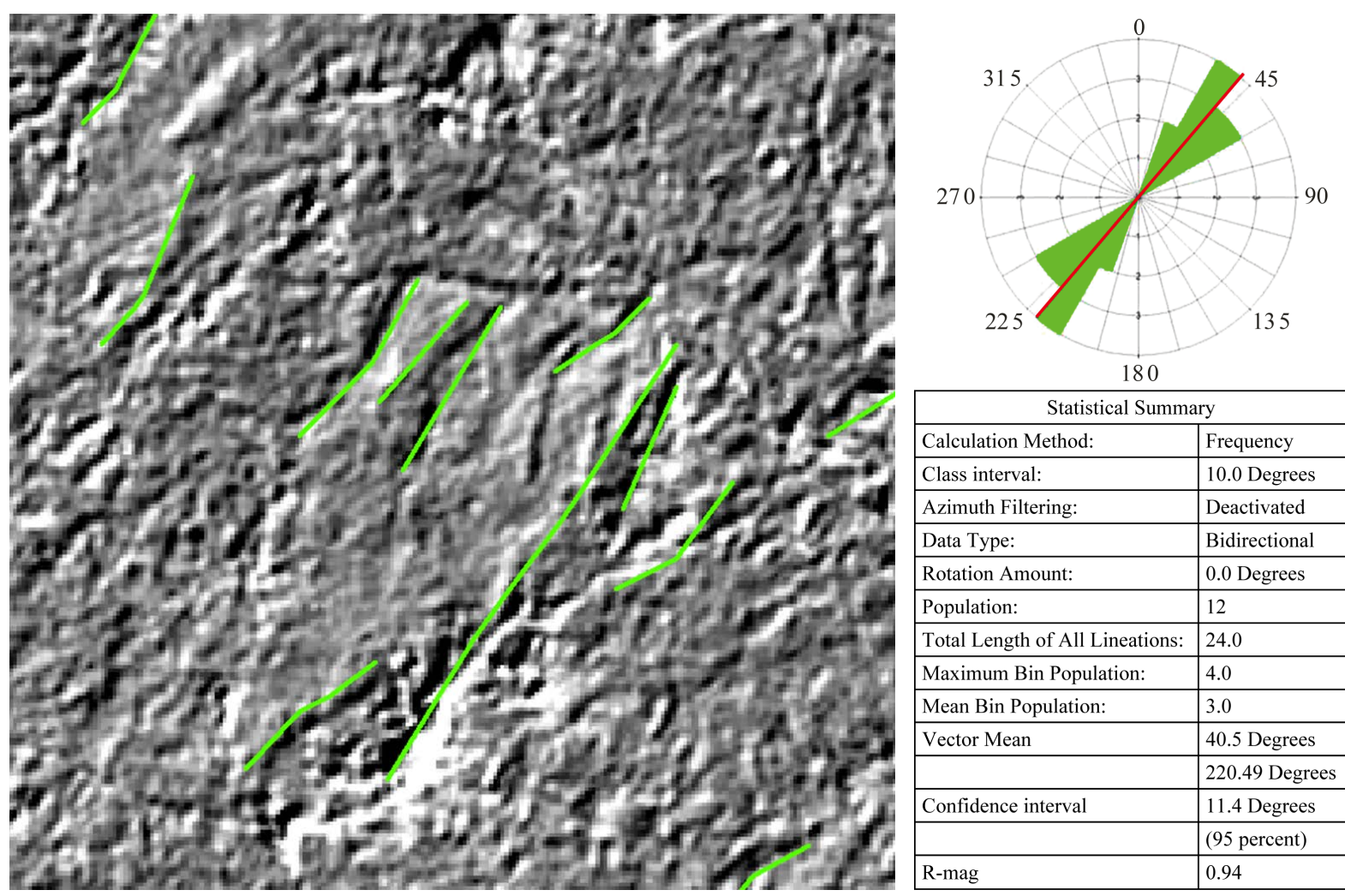

Figure 6. Map lineament and rose diagram of the north west direction (filtre $135^{\circ}$ ). 


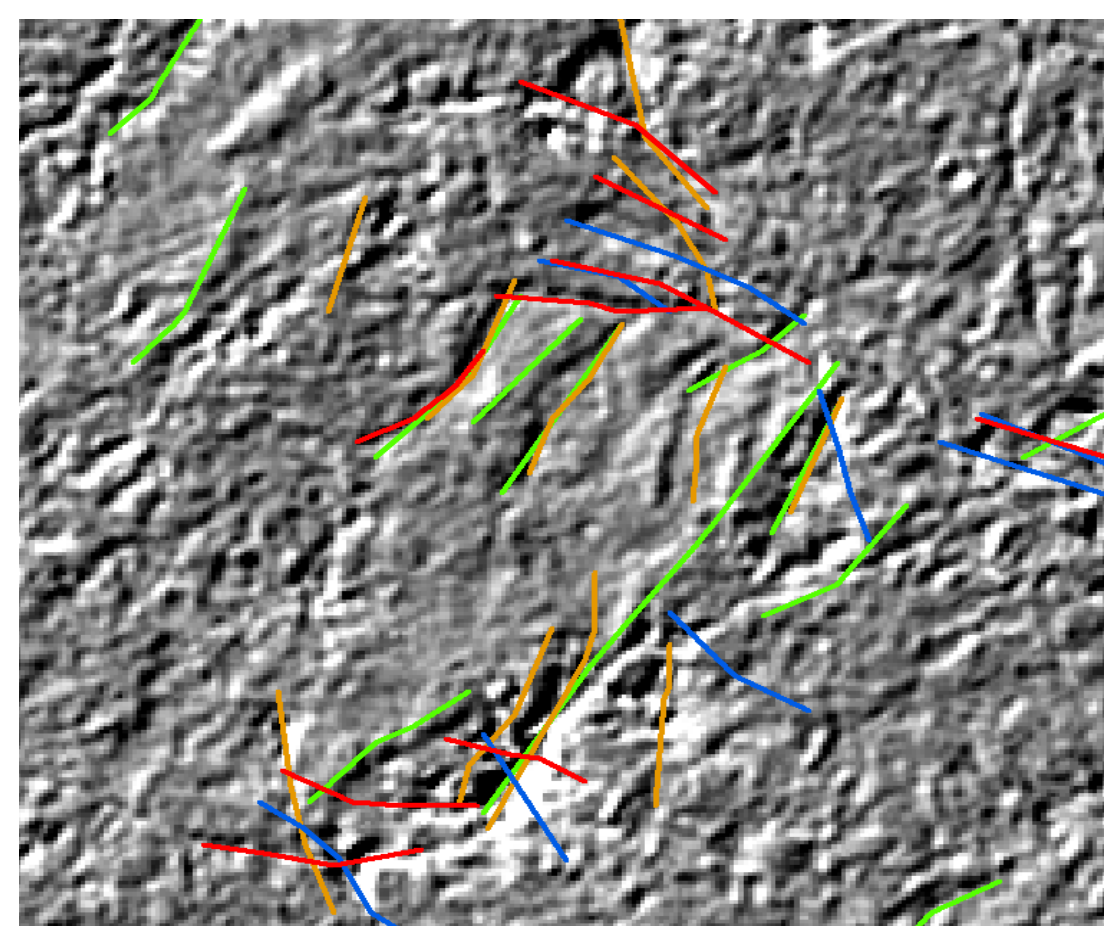

Figure 7. Synthetic lineaments map.

Table 3. Characteristics of the various lineaments for the study area.

\begin{tabular}{ccc}
\hline Lineaments map & Numbers of the lineaments & Total lineament length $(\mathrm{km})$ \\
\hline North-west & 12 & 24 \\
South-west & 8 & 16 \\
South & 9 & 18 \\
West & 11 & 22 \\
Total & 40 & 80 \\
\hline
\end{tabular}

The lineament map and therose diagram W (Figure 5), indicates a heterogeneous lineament with an ascendancy of the lineaments of NW-SE trend.

The statistical analysis of lineaments obtained by filtering NW (filters 135 lineaments) indicates a preferential direction (NW-SE) (Figure 6).

The map of synthesis of lineaments (Figure 7) represents all the segments resulting from the overlapping of the information contained in four filtered images, it groups 40 lineaments, with a total length of $80 \mathrm{~km}$. The diagram of the frequencies indicates two important families of orientations of lineaments: NE-SW and SW-NE.

The treatments of the satellite image, compared with the result of the geophysics studies realized in this sector, have been recorded. The results of treatment and the exploitation gravimetric realized by Fahem.k [22] proved the existence of two families of lineaments NE-SW and NW-SE. Fahem.k [22] indicated that the Numidien shows an evolution in the time and in the space and indicates that the direction NE-SW is the oldest and the direction NW-SE is more recent.

Comparing the lineament map with the fault lines digitalized from the published geological map (Figure 8), the result shows that the remote sensing approach produced more lineament. Possible reason for this could be the study area is composed of dense vegetation, which obscures the reflectance of the bedrock deformation on the imagery.

The comparison of the faults found in the lineaments map by automatic extraction with the faults of the geologic map of the zone of study asserts the existence of the direction NE-SW, but the direction NW-SE exist 


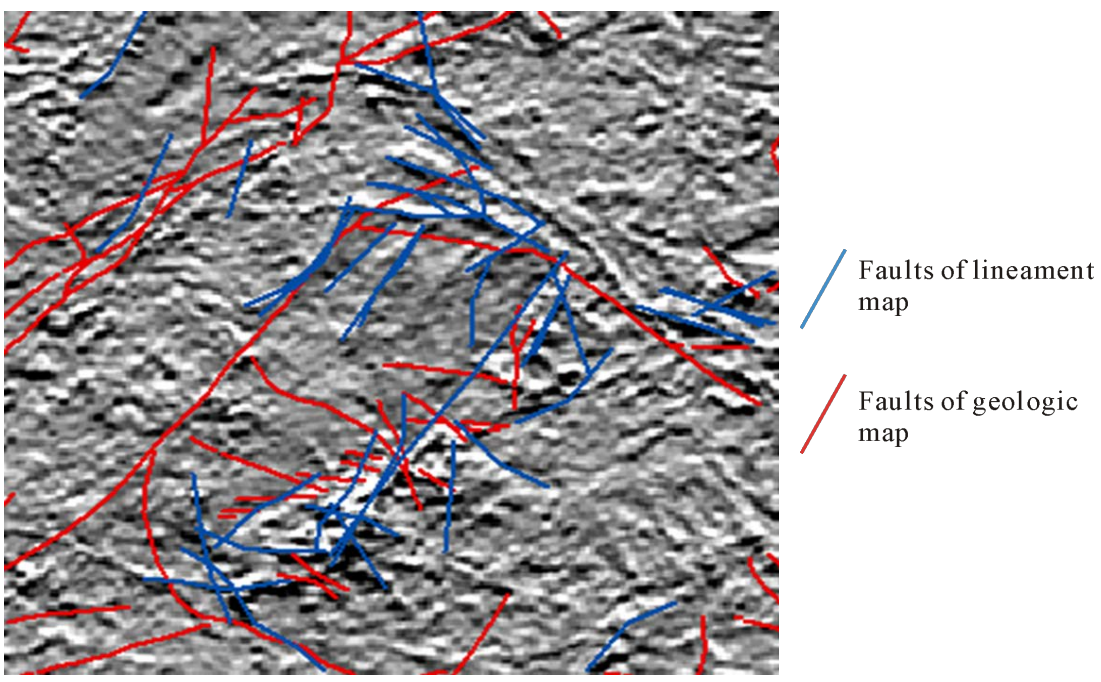

Figure 8. The comparison of the faults found in the lineaments map by automatic extraction with the faults of the geologic map of the zone of study.

more in lineaments map than the geologic map (Figure 8). This conflict is justified by Rouvier [11] which indicates that the zone of study knew a phase of Neogene comment coats and what the accidents of orientation NW-SE correspond to the fractures of extension of the anté-pliocene compression.

\section{Conclusions}

The remote detection constitutes a powerful tool for the researches concerning the prospecting of subterranean waters. It is a method of investigation adapted to the hydrogeologic prospecting of fractured aquifers. The treatment and the analysis of image Landsat 5 TM allowed map of fractures in the region of Zahret Median.

However, the analysis by remote detection did not allow specifying if the identified fractures were hydraulically active, that is if these fractures constituted reservoirs of subterranean waters. The map of fracturing obtained by satellite image must be coupled with the hydrogeological data through a SIG for a better exploitation of water resources. This approach permits to identify, with confidence, more zones favorable to the setting-up of the drillings for the supply of drinking water to the rural populations, even to large cities.

In the future, we intend to couple these results with the data hydrodynamics (debits, transmissivity, permeability, etc.) to optimize the hydrogeological studies and reduce considerably the rate of failure during the settingup of the drillings. Then, this should allow approaching the problem of subterranean flows on the system fractured through a digital modeling.

\section{References}

[1] Abdullah, A., Akhir, J.M. and Abdullah, I. (2010) Automatic Mapping of Lineaments Using Shaded Relief Images Derived from Digital Elevation Model (DEMs) in the Maran-Sungai Lembing Area, Malaysia. Electronic Journal of Geotechnical Engineering, 15, 949-957.

[2] Abdullah, A., Akhir, J.M. and Abdullah, I. (2010) The Extraction of Lineaments Using Slope Image Derived from Digital Elevation Model: Case Study: Sungai Lembing - Maran Area, Malaysia. Journal of Applied Sciences Research, 6, 1745-1751.

[3] Abdullah, A., Nasser, S. and Ghaleeb, A. (2013) Landsat ETM-7 for Lineament Mapping Using Automatic Extraction Technique in the SW Part Taiz Area, Yemen. Global Journal of Human Social Science (B), XIII, 35-38

[4] Aboyeji, O.S., Mogaji, K.A. and Oyinloye, R.O. (2012) Structural Interpretation of Remotely Sensed Sets, It Hydrogeological Implication over Ile-Life and Environs. Ozen Journal of Applied Sciences, 5, 43-54.

[5] Biémi, J. (1992) Contribution à l'étude géologique, hydrogéologique et par télédétect ion des bassins versants subsahéliens du socle précambrien d’Afrique de l’Ouest: Hydrostructurale, hydrodynamique, hydrochimie et isotopie des aquifères discontinus de sillons et aires granitiques de la Haute Mara houé Côte d' Ivoire. Thèse de doctorat ès Sciences Naturelles, Université d'Abidjan, 493 p. 
[6] Hobbs, W.H. (1904) Lineaments of the Atlantic Border Region. Geological Society. American Bulletin, 15, $483-506$.

[7] Jackson, T.J. (2002) Remote Sensing of Soil Moisture: Implications for Groundwater Recharge. Hydrogeology Journal, 10, 40-51. http://dx.doi.org/10.1007/s10040-001-0168-2

[8] Jourda, J.P. (2005) Méthodologie d'application des techniques de télédétection et des systèmes d’information géographique à l'étude des aquifères fissurés d'A frique de l'ouest. Concept de l'Hydrotechniquespatia le: Cas des zones tests de la Côte d'Ivoire. Thèse de doctorat ès Sciences Naturelles, Université de Cocody-Abidjan, Côte d’Ivoire, 429 p.

[9] Jourda, J.P., Saley, M.B., Djagoua, E.V., Kouamé, K.J., Biémi, J. and Razack, M. (2006) Utilisation des données ETM+ de Landsat et d'un SIG pour l'évaluation du potentiel en eau souterraine dans le milieu fissuré précambrien de la région de Korhogo (nord de la Côte d’Ivoire): Approche par analyse multicritère et test de validation. Télédétection, 5, 339-357.

[10] Khalifa, F. (2004) Expression géophysique et interprétation structurale dans la région de Nefza-ZahretMedien Apports de la gravimétrie. D.E.A.Université Tunis II,131p.

[11] Khomsi, S. (1998) Deformations ante-miocene moyen et structuration tardive dans la région de zahret Medien (Tunisie septentrionale). D.E.A. Université Tunis II, 75 p.

[12] Kouamé, K.F., Gioan, P., Biémi, J. and Affian, K. (1999) Méthode de cartographie des discontinuités-images satellitales: Exemple de la région semi-montagneuse à l’ouest de la Côte d’Ivoire. Télédétection, 2, 139-156.

[13] Kouamé, K.F., Akaffou, A.G., Lasm, T., De Dreuzy, J.R., Davy, P. and Bour, O. (2005) Simulation des écoulements dans les réservoirs fracturés: Application au socle Archéen de Touba (Nord-Ouest de la Côte d'Ivoire). Actes du Colloque Internationale SITIS 05, Yaoundé (Cameroun), 27 November-1 Décember 2005, 39-46.

[14] Krishnamurthy, J., Venkatesa Kumar, N., Jayaraman, V. and Manivel, M. (1996) An Approach to Demarcate Ground Water Potential Zones through Remote Sensing and a Geographic Information System. International Journal of Remote Sensing, 17, 1867-1884. http://dx.doi.org/10.1080/01431169608948744

[15] Lasm, T. (2000) Hydrogéologie des réservoirs fracturés de socle: Analyses statistiques et géostatistique de la fracturation et des propriétés hydrauliques. A pplication à la région des montagnes de Côte d’Ivoire Domaine Archéen). Thèse de doctorat, Université de Poitiers, Poitiers, 272 p.

[16] Lloyd, J.W. (1999) Water Resources of Hard Rock Aquifers in Arid and Semi-Arid Zones. UNESCO, Paris.

[17] Rouvier, H. (1977) Gitologie de l'extrême Nord de la Tunisien: Tectonique et paléogéographies superposées à l'extrémité orientale de la chaine nord-maghrébine. Ann. Min et Géo.,Tunisie, No. 29, 427 p.

[18] Rouvier, H. (1990) Carte géologique de Zahret Medien à l'echelle 1/50000. Ed.O.N.M.

[19] Savané, I. (1997) Contriution à l'étude géologique et hydrogéologique des aquifères discontinus du socle cristallin d'Odienné Nord-Ouest de la Côte d'Ivoire). Apports de la télédétection et d'un Système d'Information Hydrogéologique à Référence Spatiale. Thèse de doctorats Sciences Naturelles, Université d’Abidjan-Côte d’Ivoire, 386 p.

[20] Youan Ta, M. (2008) Contribution de la télédétection et des systèmes d'informations géographiques à la prospection hydrogéologique du socle précambrien d’Afrique de l'Ouest: Cas de la région de Bondoukou Nord Est de la Côte d'Ivoire. Thèse de doctorat unique, Université de Cocody-Abidjan (Côte d'Ivoire), 236 p.

[21] Youan Ta, M., Lasm, T., Jourda, J.P., Kouame, K.F. and Razack, M. (2008) Cartographie des accidents géologiques par imagerie satellitaire Landsat-7 ETM+ et analyse des réseaux de fractures du socle précambrien de la région de Bondoukou (nord-est de la Côte d’Ivoire). Télédétection, 2, 34-42.

[22] PCI Geomatica (2001) PCI Geomatica User’s Guide Version 9.1. Richmond Hill, Ontario. 